\title{
O TEMPO SOMBRIO DAS ACUSAÇÕES AOS CRISTÃOS NOS DOIS PRIMEIROS SÉCULOS DO CRISTIANISMO ${ }^{1}$
}

\section{The dark time of accusations to christians in the two first centuries of christianity}

\author{
Heber Ramos Bertuci²
}

\begin{abstract}
Resumo:
A síntese histórica que este artigo descreve é restrita aos dois primeiros séculos da era cristã. Seu objetivo é descrever as dificuldades que os cristãos e seu pensar teológico tiveram nesse período. O pensar teológico cristão buscava a unidade da fé e da razão - elementos necessários para que os cristãos soubessem agir com sabedoria diante das autoridades romanas. Enquanto essas enalteciam o culto do Imperador, os cristãos respondiam com respeito, obediência ao que não era contrário à sua fé e intercessão pelas autoridades e pelo Império. O público acusava os cristãos de três atitudes: ateísmo, imoralidade e antropofagia (ou assassinato). Levantaram-se para estudar os argumentos pagãos e respondê-los, alguns eruditos cristãos: Justino, filósofo e Mártir (c. 100 - 165), Teófilo de Antioquia († 186), Atenágoras, filósofo de Atenas (c. 133 - 190) e Tertuliano de Cartago (155 - 220). Estes se colocaram como porta-vozes da Igreja, defendendo o nascente pensar teológico cristão, utilizando fé, razão, respeito e diálogo.
\end{abstract}

Palavras-Chave: Pensar Teológico; Acusações aos Cristãos; Defesa da Fé.

\begin{abstract}
:
The historical synthesis that this article describes is restricted to the first two centuries of the Christian era. Its purpose is to describe the difficulties that Christians and their theological thinking had during this period. Christian theological thinking is about the unity of faith and reason - necessary elements for Christians to know how to act wisely before the Roman authorities. While these authorities praise the Emperor's worship, Christians respond with respect, obedience to what was not contrary to their faith and intercession by the authorities and the Empire. The public accused Christians of three attitudes: atheism, immorality and anthropophagy (or murder). Some Christian scholars arose to study the pagan arguments and answer them: Justin, Philosopher and Martyr (c. $100-165)$, Theophilus of Antioch ( +186$)$, Athenagoras, philosopher of Athens (c. 133 - 190) and Tertullian of Carthage (155 - 220). These stood as spokesmen for the Church, defending the nascent Christian theological thinking, using faith, reason, respect and dialogue.
\end{abstract}

Key Words: Theological Thinking; Persecution of Christians; Defense of Faith.

1 Submetido em: 01.04.2020. Aceito em: 17.09.2020.

2 Graduado e Mestre em Teologia pela Universidade Presbiteriana Mackenzie, SP. Doutorando em Teologia na Pontifícia Universidade Católica do Rio de Janeiro, PUC-Rio. Contato: heber-rb@outlook.com

Protestantismo em Revista | São Leopoldo | v. 46, n. 01 | p. 110-121| Jan./jun. 2020

Disponível em: <http://periodicos.est.edu.br/index.php/nepp> 


\section{Introdução}

Um dos grandes personagens da incipiente Igreja Cristã foi Policarpo (c. 69 - 165), denominado por Irineu de Lion (c. 135 - 202) de testemunha da verdade. ${ }^{3}$ Policarpo conviveu pessoalmente com pessoas que tinham visto Jesus e foi estabelecido Bispo na Ásia Menor, ${ }^{4}$ em Esmirna, talvez pelo próprio apóstolo João. Policarpo, diante de notícias que indicavam dificuldades para a Igreja - como, por exemplo, heresias - tinha o costume de lançar um grito, tampar os ouvidos e afirmar: "Deus bondoso! Até que tempos me conservaste, para ter que suportar estas coisas!" 5 Esta frase representa o brado dos cristãos diante das dificuldades: as más notícias os fazem elevar os olhos a Deus e refletir sobre o motivo de vivenciar, em sua geração, tais adversidades. A negação dessas dificuldades é uma das possíveis causas da derrota, contudo o seu enfrentamento sincero é o primeiro passo para descobrir a solução.

A síntese histórica que este artigo descreve é restrita aos dois primeiros séculos da era cristã. Seu tema é: $O$ tempo sombrio das acusações aos cristãos nos dois primeiros séculos do cristianismo, cujo objetivo é descrever as dificuldades que os cristãos tiveram neste período. O tema se desenvolverá em três pontos. O primeiro tem como título: Fé e razão no pensar teológico cristão. Nele, é explicado que o pensar teológico cristão busca a unidade da fé e da razão, as quais se unem para determinar que a teologia cristã não é mito, razão impessoal ou conteúdo meramente político que torne possível a vida social de uma cidade. Este ponto também enfatiza que o pensar teológico cristão possui três autoridades: Revelação, Tradição e Escritura Sagrada.

O segundo ponto se chama: Tempos sombrios do pensar teológico cristão diante das autoridades romanas. Nele, é concedida uma síntese das dificuldades surgidas entre a religião cristã e as autoridades do Império Romano. Será demonstrado que, apesar do respeito, obediência e intercessão que os cristãos mantinham pelo Imperador e pelo Império, um fator foi crucial para que a relação entre o cristianismo e Roma se abalasse: o antagonismo cristão em relação ao culto politeísta. Por não cultuarem o Imperador, os cristãos foram criticados. A situação se agravou, após julho de 64, quando o Imperador Nero (37 - 68) acusou os cristãos de terem ateado fogo na cidade de Roma. A partir desse momento, o nome cristão passou a ser motivo de perseguição local em Roma.

O terceiro ponto é intitulado: Tempos sombrios do pensar teológico cristão diante das acusações. Seu objetivo é descrever as três principais acusações que os cristãos sofreram nos dois primeiros séculos depois de Cristo, a saber: ateísmo, imoralidade e antropofagia (ou assassinato). Serão citados eruditos daquela época que se engajaram no intuito de refutar as acusações contra os cristãos, tais como: Justino, filósofo e Mártir (c. 100 - 165); Teófilo de Antioquia († 186); Atenágoras, filósofo de Atenas (c. 133 - 190) e Tertuliano de Cartago (155 - 220). Esses se colocaram como porta-vozes da Igreja, primeiro descrevendo as críticas que se faziam à Igreja e, depois, defendendo o nascente pensar teológico cristão, utilizando fé, razão, respeito e diálogo.

3 IRINEU DE LION, Contra as Heresias, III, 3,4.

4 IRINEU DE LION, Contra as Heresias, III, 3,4.

5 POLICARPO Apud. Irineu In EUSÉBIO DE CESAREIA, História Elesiástica, V, 20, 7.

Protestantismo em Revista | São Leopoldo | v. 46, n. 01 | p. 110-121| Jan./jun. 2020

Disponível em: <http://periodicos.est.edu.br/index.php/nepp> 


\section{Fé e Razão no Pensar Teológico Cristão}

O objetivo deste primeiro capítulo é explicar o que se entende por pensar teológico cristão. A formação do pensar teológico cristão foi, desde o início, questão de urgência na mente dos eruditos da nova religião. Isto pode ser visto na preocupação dos cristãos em responder a uma das perguntas com as quais a Igreja se deparou: "qual é o Deus da fé cristã?" De forma mais elaborada: "a qual dos deuses corresponde o Deus cristão: a Júpiter, a Dionísio, a Zeus ou a outro qualquer?" Em um mundo politeísta, a Igreja precisou interpretar corretamente a revelação divina e compreender qual a natureza de seu Deus. Esta indagação era fulcral, especialmente diante da conhecida tríplice classificação da teologia elaborada pelo filósofo romano Marco Terêncio Varrão (116 - 27 a.C.), considerado por Marco Túlio Cícero (106 - 43 a.C.) o homem mais sábio de seu tempo. ${ }^{6}$ Varrão defendeu que a teologia, a qual ele definiu como a ciência dos deuses, ${ }^{7}$ era dividida em: teologia mythica (mítica ou fabulosa),

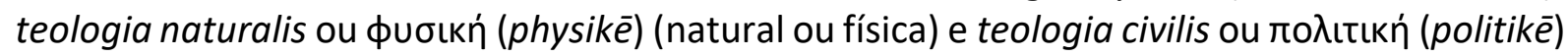
(civil ou política). Agostinho, em sua obra que contém a mais insigne apologia do cristianismo antigo, $A$ Cidade de Deus - composta de vinte e dois capítulos publicados em fascículos de 413 a 426 - preservou a explicação de Varrão sobre essa classificação como segue: ${ }^{8}$ (1) A respeito daquele que utiliza: a teologia mítica é usada pelos poetas (teólogos), a teologia natural é manuseada pelos filósofos e a teologia civil é empregada pelos povos; (2) A respeito do lugar: a teologia mítica é própria ao teatro, a teologia natural é própria ao mundo e a teologia civil é própria às cidades; (3) A respeito do conteúdo: a teologia mítica aborda as fábulas criadas pelos poetas (teólogos), a teologia natural versa sobre assuntos correlacionados aos deuses, isto é, sua essência, lugar, espécie, etc., e a teologia civil disserta sobre o culto público e sobre os ritos a que cada um está obrigado.

Essa classificação coloca os deuses como sendo frutos dos mitos, da razão ou da política. Portanto, ao perguntar a qual deus do panteão antigo pertencia o Deus cristão, a pergunta, realmente era: em qual destas três áreas o Deus cristão se insere? Observa-se, então, o grande risco de o conceito do Deus cristão ser entendido como um mito, puro pensamento ou como algo que apenas mantém uma cidade em funcionamento político. Portanto, como foi resolvida a questão? Na verdade, esta resposta era mais antiga que a incipiente Igreja cristã. A natureza do Deus cristão fora revelada já nas páginas do Antigo Testamento. Por exemplo, no livro dos Salmos e na literatura profética de Israel, há críticas aos deuses pagãos, zombados por serem fabricados e de mentira. Portanto, o Deus judaico não era um mito ou fruto da imaginação, mas era real. Segue este raciocínio o apóstolo Paulo, em seu famoso discurso no areópago grego, relatado em Atos 17,22-32, no qual ele faz referência a três poetas gregos que pronunciaram ensinos sobre Zeus, o principal deus helênico: o cretense Epimênides (c. 600 a.C.), com a frase: "pois nele vivemos, e nos movemos, e existimos"; Cleanto (331 - 233 a.C.) e o ciliciano Arato (315 - 240 a.C.), com a frase "Porque dele também somos geração". ${ }^{9}$ Os argumentos do apóstolo colocam o Deus cristão não nos mitos das religiões, mas no conceito filosófico de Deus, aquele que pretende desmitologizar as religiões. O Deus cristão também não é apresentado, por Paulo, como um ser necessário

CÍ́CERO Apud AGOSTINHO, Cidade de Deus, VI, II.

AGOSTINHO, Cidade de Deus, VI, V, 1.

AGOSTINHO, Cidade de Deus, VI, V.

9 BíBLIA DE ESTUDO DE GENEBRA, Comentário de Atos 17,28.

Protestantismo em Revista | São Leopoldo | v. 46, n. 01 | p. 110-121| Jan./jun. 2020

Disponível em: <http://periodicos.est.edu.br/index.php/nepp> 
apenas a um aspecto político da realidade. No final de seu discurso em Atenas, Paulo apresenta o Deus encarnado - Jesus Cristo - como o ponto de unidade entre pensamento e fé.

Na mesma base do prólogo do Evangelho de João $(1,1)$, Paulo enfatiza Jesus como

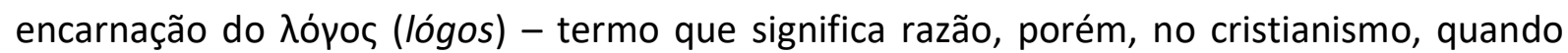
aplicado a Cristo, não indica algo impessoal, conforme a pura matemática, mas uma ampliação do conceito de razão: algo que é pessoa, que fala, que se relaciona e que se aproxima. Paulo age da mesma forma em sua epístola aos Romanos $(1,23)$, ao zombar dos deuses fabricados em imagens de aves, quadrúpedes e répteis, e apresentar Jesus Cristo, o Deus que é razão, mas também amor e salvador (Rm. 8,38-39).${ }^{10}$ Alguns antigos eruditos cristãos seguiram, veementemente, esses conceitos paulinos. Por exemplo, Justino, filósofo e mártir argumentou que o cristianismo era a vera filosofia, enfatizando que a filosofia segura e proveitosa era a que vinha dos profetas e dos homens amigos de Cristo. ${ }^{11}$ Ele afirmou que era filósofo, seguindo as doutrinas do Salvador. ${ }^{12}$ Agostinho, Bispo de Hipona (354 - 430), ao expor a tríplice divisão da teologia elaborada por Varrão (116 - 27 a.C.), não teve receio de classificar a fé cristã como física, como o triunfo do conhecimento sobre os mitos. ${ }^{13}$ Além desses, de acordo com o teólogo alemão Joseph Ratzinger (*1927), "Segundo Agostinho e a tradição bíblica, para ele determinante, o cristianismo não se fundamenta nas imagens e presságios míticos, cuja justificação reside na sua utilidade política, mas baseia-se naquele divino, cuja realidade pode ser comprovada pela análise racional."14

A classificação agostiniana foi importante para a Igreja porque ratificou que o pensar teológico cristão, desde as origens, se propõe a unir fides et ratio - fé e razão. Em tempos mais recentes, continua a ênfase na fé e na razão como caminhos dados por Deus para que os seres humanos contemplem e alcancem a verdade. Duas obras importantes sobre o assunto, na atualidade, são: a encíclica Fides et Ratio, do João Paulo II (1920 - 2005), e o livro Crer é Também Pensar, de autoria do teólogo britânico John Stott (1921 - 2011). Essas obras, unidas à literatura cristã do passado, expõem não apenas o liame entre fé e razão, mas também quais são os fundamentos do pensar teológico cristão. Esse pensar nasceu sob a autoridade da Revelação divina, da Tradição e da Escritura. Já que o objetivo deste ponto é demonstrar que, no pensar teológico cristão, há enleio entre fé e razão, não será necessário explicar essas fontes de autoridade, bem como suas interpretações ao longo da História da Igreja.

\section{Tempos Sombrios do Pensar Teológico Cristão Diante das Autoridades Romanas}

Os tempos sombrios dos dois primeiros séculos serão expostos na relação entre o cristianismo e as autoridades romanas. A pergunta a ser respondida é: de que maneira os cristãos buscavam se portar em relação ao Estado Romano? Com relação a este, o princípio da obediência era a norma, de acordo com as palavras do apóstolo Paulo registradas em

10 RATZINGER, Joseph. Fé, verdade e tolerância. São Paulo: Instituto Brasileiro de Filosofia e Ciência "Raimundo Lúlio", 2013, p. 155 - 156.

11 JUSTINO DE ROMA, Diálogo com Trifão, 8,1.

12 JUSTINO DE ROMA, Diálogo com Trifão, 8,2.

13 Agostinho, Cidade de Deus, VI, V; RATZINGER, Joseph. Fé, verdade e tolerância. São Paulo: Instituto Brasileiro de Filosofia e Ciência “Raimundo Lúlio”, 2013, p. 155.

14 RATZINGER, 2013, p. 156.

Protestantismo em Revista | São Leopoldo | v. 46, n. 01 | p. 110-121| Jan./jun. 2020

Disponível em: <http://periodicos.est.edu.br/index.php/nepp> 
Romanos 13,1. Há registros de que os cristãos deveriam reconhecer o Estado, cumprindo seus deveres de súditos e orando pelo Imperador. Por exemplo, entre os anos de 95 ou 96, Clemente de Roma (c. 35 - 97) intercede pelos chefes e pelos que governam sobre a terra, com as seguintes palavras: "Dá-Ihes, Senhor, a saúde, a paz, a concórdia e a constância, para que exerçam com segurança a soberania que Ihes deste." 15 Também Policarpo de Esmirna, explanando sobre a oração pelas autoridades, afirma: "[Orai] também pelos reis, autoridades e príncipes, pelos que vos perseguem e vos odeiam, pelos inimigos da cruz. Desse modo, o vosso fruto será manifesto em todos, e vós sereis perfeitos nele."16

Sobre a adoração ao Imperador, assunto que será explicado abaixo, o antigo Bispo da cidade de Antioquia, Teófilo, em cerca do ano de 180, explicou: "Por isso, eu honraria melhor ao imperador, embora não o adorasse, mas rogasse por ele. Adorar, eu adoro apenas ao Deus real e verdadeiramente Deus, pois sei que o imperador foi criado por ele." ${ }^{17}$ E continua: "Então me perguntarás: 'Por que não adoras o imperador?' Porque não foi constituído para ser adorado, mas para que se lhe tribute a legítima honra. Com efeito, ele não é Deus, mas homem estabelecido por Deus, não para ser adorado, mas para julgar com justiça." ${ }^{18} \mathrm{E}$ ainda conclui: "Portanto, ó homem, estás completamente equivocado em tudo. Honra ao imperador por tua adesão a ele, submetendo-te a ele, orando por ele. Fazendo isso, realizarás a vontade de Deus." ${ }^{19}$ Atenágoras também condena o culto do Imperador e, recordando-se das palavras de Paulo, em 1 Timóteo 2,1-2, pergunta, retoricamente: "Quais são os que merecem, com mais justiça, conseguir o que pedem senão nós que rogamos por vosso império, para que o herdeis, como é de estrita justiça, de pai para filho, que cresça e acresça, através da submissão de todos os homens?" ${ }^{20}$ A resposta está clara: os cristãos. Estes se beneficiam com a ordem social advinda da dinâmica de oração e obediência em relação ao império, respeito e leis justas da parte do império: "Isso também redunda em proveito nosso, para que, levando uma vida tranquila e pacífica, cumpramos animadamente tudo quanto nos é mandado." 21

Apesar de tais ênfases cristãs, um fator foi crucial para que a relação entre o cristianismo e o Estado Romano se abalasse: a relação cristã antagônica com o culto politeísta, conforme já foi demonstrado nas palavras acima de Teófilo († 186). Aos povos vencidos, Roma permitia o exercício regular de seus cultos; isto ocorreu com os judeus, que, por sua vez, também se opunham ao politeísmo. Mas os cristãos eram diferentes, pois sua religião era universal e pretendia converter os outros a sua fé monoteísta. Todavia, um dos mais fortes aspectos da religião estatal romana era o culto do Imperador. Esse culto, difundido antes no Oriente, foi estimulado por Augusto (63 a.C. - 14 d.C.), Nero (37 - 68) e Domiciano (51 - 96). $O$ culto veio na época da crise dos deuses que foi se estabelecendo na religião estatal romana. Essa crise ocorreu porque os deuses foram relegados ao puro pensamento, seres aos quais não se podia orar, nem ter com eles um relacionamento pessoal ou depositar neles algum tipo de esperança. Os indivíduos daquele tempo estavam ávidos de religião; pois se distanciaram da certeza que poderiam vencer morte e destino, e alcançar purificação espiritual, redenção

15 CLEMENTE DE ROMA, Primeira Carta aos Coríntios, 61,1.

16 POLICARPO DE ESMIRNA, Segunda Epístola aos Filipenses, 14,3.

17 TEÓFILO DE ANTIOQUIA, Primeiro Livro a Autólico, 11.

18 TEÓFILO DE ANTIOQUIA, Primeiro Livro a Autólico, 11.

19 TEÓFILO DE ANTIOQUIA, Primeiro Livro a Autólico, 11.

20 ATENÁGORAS DE ATENAS, Petição em favor dos cristãos, 37.

21 ATENÁGORAS DE ATENAS, Petição em favor dos cristãos, 37.

Protestantismo em Revista | São Leopoldo | v. 46, n. 01 | p. 110-121| Jan./jun. 2020

Disponível em: <http://periodicos.est.edu.br/index.php/nepp> 
e união com a divindade. A crise era forte porque as religiões antigas - as clássicas religiões demonstravam que pouco tinham a oferecer para satisfazer esses anseios. Assim, Augusto e seus sucessores tentaram, periodicamente, reavivar a piedade antiga, pois parecia que os deuses do passado haviam perdido qualquer poder de transmitir a antiga inspiração. Eles também enfatizaram a adoração ao Imperador. Eis alguns tipos deste culto: ${ }^{22} \mathrm{em}$ primeiro lugar, o culto iniciava através de um ato espontâneo do povo; em segundo, ocorria a apoteose do Imperador depois de morto e, então, passava a ser adorado, às vezes pela legislação do Senado; e em terceiro lugar, o próprio Imperador, vivo, proclamava-se Deus. Neste caso, geralmente, tal atitude não era bem aceita, podendo ele sofrer muito antagonismo. Estes três modos demonstram que o culto do Imperador contava com o apoio oficial, político e popular. Desta forma, cultuar o Imperador simbolizava lealdade civil, patriotismo e um sentimento de que algum tipo de providência divina velava pelo Império. Negar o culto era atitude muito ousada, sinal de aleivosia contra o próprio Império. Aqui entra a dificuldade judaica e cristã: adorar a outro deus seria crassa idolatria, o que os dois grupos não poderiam aceitar. 0 sincretismo religioso era norma na religião romana; mas não para os judeus e cristãos. ${ }^{23}$

Importante é observar que, nesses primeiros tempos do cristianismo, as autoridades não conseguiram distinguir os cristãos dos judeus: os cristãos Ihes pareciam uma seita judaica. Isto significava que os cristãos eram considerados adeptos de uma religião lícita, permitindo que eles se desenvolvessem, diante do Estado, sob tutela judaica. Essa situação mudou após o terrível incêndio que devastou Roma em julho de 64, pois o imperador Nero (37 - 68) colocou sobre os cristãos a responsabilidade pelo ocorrido, o que os levou a serem perseguidos e mortos. Tácito $(56-120)$, historiador romano da época, afirmava que os cristãos (para ele, execrável superstição), nutriam "o ódio contra o gênero humano". ${ }^{24}$ Por isso, mesmo sem acreditar que eles fossem os responsáveis pelo incêndio de Roma, Tácito declarava que eram merecedores daquela punição. ${ }^{25}$ Nero, com o objetivo de conceder um espetáculo para o povo, efetuou execuções de cristãos nos jardins imperiais, sob as seguintes formas: tochas vivas, crucificação e representações cruentas de cenas mitológicas. ${ }^{26}$ Esta perseguição de Nero aos cristãos foi realizada apenas na capital romana, durando até a morte do Imperador. Entre as vítimas cristãs, encontram-se os apóstolos Pedro e Paulo. Também é importante saber que a acusação de colocar fogo em Roma tornou o nome cristão nefando, fazendo-o ser banido e ferreteado como algo digno de morte, algo criminoso.

Havia algum fundamento jurídico nas perseguições aos cristãos no período do primeiro século da Era Cristã? É provável que, aos cristãos, tenham sido aplicados os preceitos da Lex Iulia Maiestatis, promulgada em 8 a. C., a pedido do Imperador Augusto (63 a.C. - 14 d.C.), a qual punia por alta traição, com a confiscação dos bens e a condenação à morte, os que praticassem ações hostis contra a segurança do povo romano. ${ }^{27}$ Esta lei pode ter sido

22 COLEMAN, William L. Manual dos tempos e costumes bíblicos. Venda Nova: Betânia, 1991, p. 219 - 220.

23 KELLY, John N. Davidson. Doutrinas centrais da fé cristã: origem e desenvolvimento. Tradução: Marco L. Redondo. São Paulo: Vida Nova, 1994, p. 9.

24 TÁCITO, Anais, XV, 44 apud. MORESCHINI, Claudio; NORELLI, Enrico. História da literatura cristã antiga grega e latina. São Paulo: Loyola, 1996, p. 271 - 272. (v. 1).

25 TÁCITO, Anais, XV, 44,4-5 apud MORESCHINI, Claudio; NORELLI, Enrico. História da literatura cristã antiga grega e latina. São Paulo: Loyola, 1996, p. 272. (v. 1).

26 BIHLMEYER, Karl; TUECHLE, Hermann. História da Igreja. São Paulo: Paulinas, 1963, § 15,1. (v. 1).

27 BIHLMEYER, Karl; TUECHLE, Hermann. História da Igreja. São Paulo: Paulinas, 1963, § 14,3. (v. 1).

Protestantismo em Revista | São Leopoldo | v. 46, n. 01 | p. 110-121| Jan./jun. 2020

Disponível em: <http://periodicos.est.edu.br/index.php/nepp> 
aplicada aos cristãos por serem suas práticas consideradas hostis ao culto do Imperador. Sobre leis persecutórias especiais contra os cristãos, estas podem ter sido já promulgadas desde os tempos de Nero, considerando o cristianismo um delito que deveria ser punido com a morte. Tertuliano menciona a existência de um Institutum Neronianum que era o alicerce para atuações anticristãs, ${ }^{28}$ apesar de muitos estudiosos não acreditarem que a punição do nomen cristão como um crime tivesse alguma base jurídica. Certo é que os cristãos eram vistos por magistrados com suspeita, por suas ações serem consideradas proditórias. Havia uma conduta em relação a eles, a coercitio, a qual constava de um ato de polícia por parte do magistrado local. Entretanto, se a condenação podia acontecer tendo por motivo a obstinação do cristão, a recepção da denúncia deveria ter outra base, talvez o fato de ser o cristianismo considerado uma religio illicita, "religião ilícita".

Percebe-se que, diante das autoridades romanas, os cristãos viveram períodos sombrios. Foram tempos de perseguições, em primeiro momento, por dois motivos: pelo nome cristão e pela negação do culto ao Imperador. Esta situação complicou-se mais um pouco no decorrer das décadas seguintes, com acusações que tornaram os cristãos ainda mais odiosos, não apenas diante das autoridades, mas também diante do público em geral. Isto será visto no próximo ponto.

\section{Tempos Sombrios do Pensar Teológico Cristão Diante das Acusações}

Houve três sérias acusações aos cristãos nos dois primeiros séculos depois de Cristo. Elas são descritas na obra Legatio sive Supplicatio pro Christianis (Petição em favor dos cristãos), concebida cerca de 177, por Atenágoras, e dirigida ao Imperador Marco Aurélio (121 - 180) e ao seu filho Lúcio Aurélio Cômodo (161 - 192). A primeira acusação foi a de ateísmo

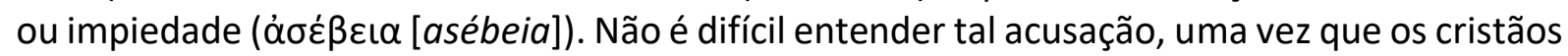
se abstinham do culto ao Estado e adoravam a Deus, sem imagens. À religião cristã foram aplicadas as antigas disposições penais de direito comum, sendo uma delas a acusação de ateísmo - crimen laesa romanae religionis -, de acordo com Tertuliano. ${ }^{29}$ Esta acusação de ateísmo era comum na cultura greco-romana. Entre os gregos, a acusação era de impiedade, asébeia, a qual podia incorrer em ateísmo. A pena por impiedade ocorria quando algum cidadão se tornava insubmisso às leis da cidade, inclusive não crendo em seu panteão. $A$ crença nos deuses era a base social da cidade, pois gerava algum tipo de ética, levava os cidadãos a respeitarem tanto o Estado como os sacerdotes e, ainda, concebia lucros. Dessa forma, não crer nos deuses significava declarar-se fora de um dos principais fundamentos da sociedade. O mais famoso processo por impiedade, que culminou em acusação de ateísmo, foi o do filósofo Sócrates (469 - 399 a.C.).

Diante dos romanos, os cristãos foram acusados de ateus pelos imperadores até a época de Constantino (272 - 337), porque desprezaram os deuses da religião oficial. Na literatura dos Pais da Igreja, encontram-se descrições desta acusação. Um exemplo é o Martyrium Polycarpi (Martírio de Policarpo), a mais antiga narração de martírio do tempo das perseguições. O texto foi composto em forma de uma carta da comunidade de Esmirna para comunidade de Filomélio, na Frígia, e escrita por certo Marcião ${ }^{30}$ pouco depois da morte de

28 TERTUliANO, Aos Pagãos, I,7-9 apud. Claudio MORESCHINI; Enrico NORELLI, 1996, p. 272. (v. 1).

29 TERTULIANO, Apologia, 24 apud. Karl BIHLMEYER; Hermann TUECHLE, 1963, § 14,3. (v. 1).

30 MARCIÃO, Martírio de São Policarpo, 20,1.

Protestantismo em Revista | São Leopoldo | v. 46, n. 01 | p. 110-121| Jan./jun. 2020

Disponível em: <http://periodicos.est.edu.br/index.php/nepp> 
Policarpo (c. 69 - 155), provavelmente no ano de 156. O texto afirma que cristãos foram levados para um circo, na cidade de Esmirna, por causa de uma perseguição ocorrida ali. 0 relato é bem vívido. Houve flagelos: "Dilacerados pelos flagelos a ponto de se ver a constituição do corpo até as veias e artérias, permaneciam firmes, enquanto os presentes choravam de compaixão." 31 Este choro, provavelmente, fosse dos cristãos presentes, por causa do sofrimento de seus irmãos. Houve aqueles que foram entregues às feras, suportando suplícios terríveis: "Estendidos sobre conchas, eram submetidos a todo tipo de tormentos, para que fossem induzidos a renegar, se possível, por meio de suplício contínuo." ${ }^{32}$ É mencionado, ainda, um homem chamado Germânico, o qual foi perseverante. O procônsul queria que ele cedesse por causa de sua juventude, mas ele atiçou a fera, chamando-a sobre si. $^{33}$ Depois disso, afirma o documento: "Então, a multidão toda, admirada diante da coragem da piedosa e crente geração dos cristãos, gritou: 'Abaixo os ateus! Trazei Policarpo'." ${ }^{34}$ Assim, os cristãos foram chamados de ateus por negarem os deuses romanos.

$\mathrm{Na}$ obra de Justino também se encontra a acusação de ateísmo aos cristãos. Adotando um conceito mais amplo de ateísmo, o de ser ateu em relação a algumas divindades, mas não a outra ou outras, Justino explica que os cristãos são ateus apenas em relação aos deuses pagãos: "Por isso, também nós somos chamados de ateus; e, tratando-se desses supostos deuses, confessamos ser ateus. Não, porém, do Deus verdadeiríssimo, pai da justiça, do bom senso e das outras virtudes, no qual não há mistura de maldade." ${ }^{35} \mathrm{E}$, alhures, adotando um conceito mais restrito de ateísmo, o de ser ateu aquele que não crê na existência de nenhum deus, Justino explica que os cristãos não são ateus: "Que não somos ateus, quem estiver em são juízo o dirá, pois cultuamos o Criador deste universo, do qual dizemos, conforme nos ensinaram, que não tem necessidade de sangue, libações ou incenso." 36

Por sua vez, Atenágoras desdenha a acusação de que os cristãos eram ateus, entendendo ser ridículo até mesmo dedicar tempo aos que fazem tal acusação. ${ }^{37}$ Para provar que é irracional denominar os cristãos de ateus, ele argumenta: “Nós, porém, distinguimos Deus da matéria e demonstramos que uma coisa é Deus e outra a matéria, e que a diferença entre um e outro é imensa, pois a divindade é incriada e eterna, contemplável apenas pela inteligência e pela razão, mas a matéria é criada e corruptível." 38

A segunda acusação contra os cristãos afirma que eles cometiam imoralidade, isto é, orgias e atos incestuosos. Essa acusação se embasava no que a população ouvia, equivocadamente, sobre alguns costumes e crenças dos cristãos. Um dos casos foi a lenda de que a Ágape (ou festa cristã do amor) levava à orgia. Afirmava-se que os cristãos, depois de comerem e beberem bastante, apagavam as luzes e realizavam as mais desordenadas uniões sexuais, inclusive edipoidéia (incesto). Dessa acusação dão testemunho alguns Pais da Igreja. Justino, por exemplo, pergunta ao judeu Trifão: “Ou nossa vida e moral também é objeto de

31 MARCIÃO, Martírio de São Policarpo, 2,2.

32 MARCIÃO, Martírio de São Policarpo, 2,4.

33 MARCIÃO, Martírio de São Policarpo, 3,1.

34 MARCIÃO, Martírio de São Policarpo, 3,2.

35 JUSTINO DE ROMA, 1 Apologia, 6,1.

36 JUSTINO DE ROMA, 1 Apologia, 13,1.

37 ATENÁGORAS DE ATENAS, Petição em favor dos cristãos, 4.

38 ATENÁGORAS DE ATENAS, Petição em favor dos cristãos, 4.

Protestantismo em Revista | São Leopoldo | v. 46, n. 01 | p. 110-121| Jan./jun. 2020

Disponível em: <http://periodicos.est.edu.br/index.php/nepp> 
calúnia entre vós? Quero dizer, por acaso também acreditais que [...] depois do banquete, apagadas as luzes, nos entregamos a uniões ilícitas?" 39 Em outro texto, Justino também menciona que os críticos afirmavam que os cristãos se uniam promiscuamente. ${ }^{40}$ Teófilo de Antioquia descreve que como os pagãos censuravam os cristãos, "... espalhando que temos mulheres em comum e que não nos importamos com quem nos unimos; além disso, dizem que mantemos relação carnal com nossas próprias irmãs." ${ }^{41}$ Também Atenágoras critica que os cristãos sejam acusados de praticarem imoralidade. Ele responde que o cristão não pratica imoralidades sexuais porque sabe que, com tais atitudes, peca contra Deus e não herda a vida eterna:

\begin{abstract}
Sabendo, porém, como sabemos, que Deus vigia nossos pensamentos e nossas palavras, tanto de dia como de noite, e que ele é todo luz e vê até dentro do nosso coração; acreditando, como cremos, que, ao sair desta vida, viveremos outra melhor, contanto que permaneçamos com Deus e por Deus inquebrantáveis e superiores às paixões, com alma não carnal, mas com espírito celeste, embora na carne; ou acreditando que, se cairmos como os demais, espera-nos uma vida pior no fogo (porque Deus não nos criou como rebanhos ou bestas de carga, de passagem, só para morrer e desaparecer); crendo nisso, dizíamos, não é lógico que nos entreguemos voluntariamente ao mal e nos joguemos a nós mesmos nas mãos do grande juiz para sermos castigados. ${ }^{42}$
\end{abstract}

Atenágoras confirma: "Como temos esperança na vida eterna, desprezamos as coisas da vida presente e até os prazeres da alma, tendo cada um de nós por mulher aquela que tomou conforme as leis estabelecidas por nós e com a finalidade de procriar filhos." 43 Essas palavras demonstram que o cristianismo possui ética firme, podendo ser considerado o mais alto padrão moral. Sendo assim, o cristão não pode ser condenado de imoralidade. A moral cristã se embasa em Deus e na obediência aos seus mandamentos.

A terceira acusação contra os cristãos afirmava que eles cometiam antropofagia, isto é, comiam carne humana. Essa acusação popular também se embasava em relatos deturpados acerca de costumes cristãos. Neste caso, a Eucaristia foi alvo de má interpretação: a afirmação de que Cristo estava, de algum modo, presente na refeição eucarística, levou à declaração de que os cristãos praticavam antropofagia. Segundo os falsos relatos, os cristãos cobriam uma criança com farinha de trigo e, alegando que era um pão, ordenavam que um neófito a cortasse. Quando o sangue da criança começava a jorrar, os cristãos a devoravam. Se um neófito estivesse presenciando a cena, ele deveria participar, sendo coagido a ficar em silêncio. Este testemunho é relatado por Justino. Ele pergunta a Trifão: “... por acaso também acreditais que devoramos os homens...?". ${ }^{44}$ No primeiro volume da Apologia, Justino assevera que alguns pagãos cometem atos dignos de censura e não são punidos por isso. Dentre os exemplos, ele cita um certo Simão, Samaritano, o qual fez prodígios mágicos na cidade de Roma, sendo, depois, considerado Deus e honrado com uma estátua com a inscrição latina: $A$ Simão, Deus Santo. Depois, cita o nome de uma mulher, Helena, a qual naquele tempo

39 JUSTINO DE ROMA, Diálogo com Trifão, 10,1.

40 JUSTINO DE ROMA, 1 Apologia, 26,7.

41 TEÓFILO DE ANTIOQUIA. Terceiro Livro a Autólico, 4.

42 ATENÁGORAS DE ATENAS, Petição em favor dos cristãos, 31.

43 ATENÁGORAS DE ATENAS, Petição em favor dos cristãos, 33.

44 JUSTINO DE ROMA, Diálogo com Trifão, 10,1.

Protestantismo em Revista | São Leopoldo | v. 46, n. 01 | p. 110-121| Jan./jun. 2020

Disponível em: <http://periodicos.est.edu.br/index.php/nepp> 
acompanhou Simão em suas peregrinações, sendo que a mesma antes estivera no prostíbulo. Ela é denominada de primeiro pensamento nascido dele. Após citar outros exemplos, Justino declara às autoridades: "Ora, se também eles praticam todas essas vergonhosas obras que se propalam contra nós, isto é [...] alimentarmo-nos de carnes humanas, não o sabemos. Todavia, estamos certos de que não são perseguidos, nem condenados por vós, ao menos por causa de suas doutrinas." 45 Teófilo de Antioquia, sobre essa acusação, afirma que ela é bastante ímpia e cruel. ${ }^{46}$

Além destes autores, também Atenágoras se manifesta contra a afirmação de que os cristãos comem carne humana. Ele assegura que ninguém pode afirmar que foi testemunha ocular dos cristãos cometerem tal barbaridade. Seu argumento é que isto significaria que o cristianismo é assassino, o que não condiz com os fatos, já que os cristãos não concordam, sequer, com as matanças ocorridas nos espetáculos de gladiadores. Ele pergunta: "De fato, os que sabem que não suportamos ver uma execução com justiça, como vão nos acusar de matar e comer homens? Quem de vós não se entusiasma em ver os espetáculos de gladiadores ou de feras, principalmente os que são organizados por vós?" ${ }^{47}$ E responde: "Nós, porém, que consideramos que ver matar está próximo do próprio matar, nos abstemos de tais espetáculos"48 Outro argumento de Atenágoras é que os cristãos creem que os corpos ressuscitarão e farão parte do juízo final e da bênção eterna ou castigo eterno. Isso significa que o cuidado com o corpo é essencial no cristianismo. Portanto, ele não deve ser devorado. ${ }^{49}$

Essas três acusações demonstram quão sombrio foi para qualquer indivíduo declarar que era cristão nos primeiros séculos depois de Cristo. Não que o cristianismo, em si, tivesse algo de sombrio; a dificuldade estava quando as práticas cristãs não eram compreendidas e mitos eram inventados acerca delas. Observa-se que estudiosos se empenharam em defender a fé cristã desses ataques infundados, utilizando a força do argumento, a qual constata as acusações e responde a elas em coerência e diálogo.

\section{Considerações Finais}

O pensar teológico cristão, desde suas origens, reconheceu que seu conteúdo tem como autoridade a Revelação, a Tradição e a Escritura Sagrada. Esse pensar teológico não tem como base os mitos, conforme as religiões pagãs; nem a política, servindo meramente para conceder sustentação governamental a Estados; nem a razão impessoal. O pensar teológico cristão envolve fé e razão, porque reconhece nelas o caminho dado por Deus para a contemplação e o alcance da verdade. Já nos dois primeiros séculos, o pensar teológico se viu rodeado de argumentos que tentaram ou diminuir sua dinâmica ou calá-lo. Havia a necessidade de dialogar com as autoridades romanas. Isto foi feito por meio da ética com a atitude de obedecer as regras que não ferissem seus princípios, interceder pelo Imperador e explicar as crenças cristãs para que elas ganhassem relevância social. Além do embate com o Império Romano, houve também no seio popular algumas acusações que visavam manchar a reputação cristã: ateísmo, imoralidade e assassinato. Diante de tais acusações, eruditos se

45 JUSTINO DE ROMA, 1 Apologia, $26,7$.

46 TEÓFILO DE ANTIOQUIA. Terceiro Livro a Autólico, 4.

47 ATENÁGORAS DE ATENAS, Petição em favor dos cristãos, 35.

48 ATENÁGORAS DE ATENAS, Petição em favor dos cristãos, 35.

49 ATENÁGORAS DE ATENAS, Petição em favor dos cristãos, 36.

Protestantismo em Revista | São Leopoldo | v. 46, n. 01 | p. 110-121| Jan./jun. 2020

Disponível em: <http://periodicos.est.edu.br/index.php/nepp> 
levantaram para defender a fé cristã, explicando os mal-entendidos e apresentando a verdade.

Aquele tempo era sombrio para a incipiente fé cristã. A importância das dificuldades enfrentadas no período estava no fato de que, diante das acusações, os cristãos tiveram a oportunidade de fortalecer os seus argumentos em defesa da fé e compreender melhor sua doutrina. O momento também foi importante para que os cristãos compreendessem as palavras em que Jesus, primeiro, apresenta a realidade do sofrimento humano e, depois, concede o modelo ideal a seguir: ele mesmo. Eis o texto: "No mundo, passais por aflições; mas tende bom ânimo; eu venci o mundo" (João 16,33).

Toda época tem o seu período sombrio. A atual também possui. O papel dos cristãos diante das dificuldades é imitar a fé, a razão e a ousadia dos cristãos dos primeiros séculos do cristianismo. É evidente que, no tempo atual, muitas dificuldades precisam de outras respostas porque são diferentes das que ocorreram no primeiro século. Entretanto, o fundamento destas respostas é sempre o mesmo: permanecer na fé e vencer o que é equivocado. Do mesmo modo que a mensagem cristã resistiu às acusações que sofreu nos primeiros séculos, sua ênfase na esperança em Cristo será a base para que a verdade alcance êxito nos tempos sombrios atuais.

\section{Referências}

AGOSTINHO. A cidade de Deus. Tradução: Oscar P. Leme. 14. ed. Petrópolis: Vozes; Bragança Paulista: Editora Universitária São Francisco, 2018. Parte I: Livros I a X. (Coleção Pensamento Humano).

AGOSTINHO. A cidade de Deus. Tradução: Oscar P. Leme. 8. ed. Petrópolis: Vozes; Bragança Paulista: Editora Universitária São Francisco, 2013. Parte II: Livros XI a XXII. (Coleção Pensamento Humano).

ATENÁGORAS DE ATENAS. Petição em favor dos cristãos. In: QUINTA, Manoel (Ed.). Padres apologistas. Tradução: Ivo Storniolo / Euclides M. Balancin. São Paulo: Paulus, 2014. p. 111 202. (Coleção Patrística, n. 2).

BÍBLIA DE ESTUDO DE GENEBRA. 2. ed. rev. e ampl. Barueri: Sociedade Bíblica do Brasil; São Paulo: Cultura Cristã, 2009.

BÍBLIA Sagrada. Tradução: João Ferreira de Almeida. 2. ed. rev. e atual. Barueri: Sociedade Bíblica do Brasil, 2018.

BIHLMEYER, Karl; TUECHLE, Hermann. História da Igreja. Tradução: Ebion de Lima. São Paulo: Paulinas, 1963. (V. 1: Antiguidade Cristã).

COLEMAN, William L. Manual dos tempos e costumes bíblicos. Tradução: Myrian T. Lins. Venda Nova: Betânia, 1991.

EUSÉBIO DE CESAREIA. História eclesiástica. Tradução: Wolfgang Fischer. São Paulo: Novo Século, 1999.

IRINEU DE LIÃO. Contra as heresias. Tradução: Lourenço Costa. 3. ed. São Paulo: Paulus, 2009. (Coleção Patrística, n. 4).

Protestantismo em Revista | São Leopoldo | v. 46, n. 01 | p. 110-121| Jan./jun. 2020

Disponível em: <http://periodicos.est.edu.br/index.php/nepp> 
JOÃO PAULO II. Carta Encíclica Fides et Ratio. São Paulo: Paulinas, 2006. [Promulgada em 14 de setembro de 1998]. (Coleção A voz do Papa, n. 160).

JUSTINO DE ROMA. Diálogo com Trifão. In: Idem, I e II Apologias; Diálogo com Trifão. Tradução: Ivo Storniolo; Euclides M. Balancin. São Paulo: Paulus, 2013. p. 109 - 324. (Coleção Patrística, n. 3).

JUSTINO DE ROMA. I Apologia. In: Idem, I e II Apologias; Diálogo com Trifão. Tradução: Ivo Storniolo; Euclides M. Balancin. São Paulo: Paulus, 2013. p. 19 - 85. (Coleção Patrística, n. 3).

JUSTINO DE ROMA. I e II Apologias; Diálogo com Trifão. Tradução: Ivo Storniolo; Euclides M. Balancin. São Paulo: Paulus, 2013. (Coleção Patrística, n. 3).

KELLY, John N. Davidson. Doutrinas centrais da fé cristã: origem e desenvolvimento. Tradução: Marco L. Redondo. São Paulo: Vida Nova, 1994.

MARCIÃO. Martírio de São Policarpo. In: QUINTA, Manoel (Ed.). Padres apostólicos. Tradução: Ivo Storniolo / Euclides M. Balancin. São Paulo: Paulus, 2013. p. 147 - 157. (Coleção Patrística, n. 1).

MORESCHINI, Claudio; NORELLI, Enrico. História da literatura cristã antiga grega e latina: de Paulo à era Constantiniana. Tradução: Marcos Bagno. São Paulo: Loyola, 1996. (v. 1).

POLICARPO DE ESMIRNA. Segunda Epístola aos Filipenses. In: QUINTA, Manoel (Ed.). Padres apostólicos. Tradução: Ivo Storniolo / Euclides M. Balancin. São Paulo: Paulus, 2013. p. 139 157. (Coleção Patrística, n. 1).

RATZINGER, Joseph. Fé, verdade e tolerância: o cristianismo e as grandes religiões do mundo. Tradução: Sivar H. Ferreira. São Paulo: Instituto Brasileiro de Filosofia e Ciência "Raimundo Lúlio", 2013.

STOTT, John. Crer é também pensar. Tradução: Milton A. Andrade. São Paulo: ABU, 2001.

TEÓFILO DE ANTIOQUIA. Primeiro Livro a Autólico. In: QUINTA, Manoel (Ed.). Padres apologistas. Tradução: Ivo Storniolo / Euclides M. Balancin. São Paulo: Paulus, 2014. p. 215 227. (Coleção Patrística, n. 2).

TEÓFILO DE ANTIOQUIA. Terceiro Livro a Autólico. In: QUINTA, Manoel (Ed.). Padres apologistas. Tradução: Ivo Storniolo / Euclides M. Balancin. São Paulo: Paulus, 2014. p. 273 311. (Coleção Patrística, n. 2). 